\title{
Actualization of Digital Marketing Society 5.0 on MSMES of Sasirangan Cloth in Village Sasirangan in Banjarmasin City
}

\author{
Tino Kemal Fattah ${ }^{1}$, Putriana Salman ${ }^{2}$ \\ ${ }^{1,2}$ Departemen Accounting, Politeknik Negeri Banjarmasin, Banjarmasin, Indonesia
}

\begin{tabular}{l}
\hline Article Info \\
\hline Article history: \\
Received Oct 12, 2021 \\
Revised Dec 10, 2021 \\
Accepted Dec 25, 2021 \\
\hline
\end{tabular}

\section{Keywords:}

Digital Marketing Sasirangan MSMEs Society 5.0

\begin{abstract}
Marketing is part of the main activities carried out by traders in their efforts to maintain the survival of their business to achieve business goals. Strategy is a process of determining an organizational goal, accompanied by the preparation of a way or effort how to achieve that goal. In particular, strategy is an action that is increasing and continuous and is done based on the point of view of what customers expect in the future. This research aims to find out how the actualization of digital marketing of MSMEs in the era of society 5.0. This research method uses quantitative descriptive methods with data collection techniques through questionnaire sharing. The population in this study is MSMEs Kain Sasirangan in Kampung Sasirangan Banjarmasin City. The results of this study show that Sasirangan MSMEs have used digital marketing in the process of buying and selling their products. It is recognized that the utilization of digital marketing can expand market reach and add new customers, facilitate business management with more flexible time, can be done at any time without having to open a store first, so that the profits obtained are also greater. In addition, by utilizing digital marketing, MSME sasirangan fabric actors do not need a place to sell their products, so the costs incurred are also less. Their lack of ability to use technology, only able to make them do marketing their products traditionally.
\end{abstract}

This is an open access article under the CC BY-SA license.

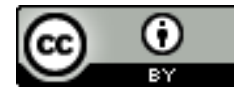

\section{Corresponding Author:}

Tino Kemal Fattah

Department of Accounting, DIII Accounting Study Program,

Politeknik Negeri Banjarmasin,

Jl. Brig Jend. Hasan Basri, Kec. Banjarmasin Utara, Banjarmasin City 70124, South Kalimantan, Indonesia. Email: tino@akuntansipoliban.ac.id

\section{INTRODUCTION}

Society 5.0 is an industry change proposed by Japanese Prime Minister Shinzo Abe in March 2017. Society 5.0 is a "solution" to the Industrial Revolution 4.0, where many people assume that Industry 4.0 will use technologically advanced machines which then suppresses the amount of work done by human power. Society 5.0 is expected to be able to create new points through the development of advanced technology so as to reduce the gap between humans and economic conflicts in the future. Basically, society 5.0 was created to serve human needs, so that human and technological synergy can be realized so that society is more prosperous.

The idea of society 5.0 is an attitude that explains if you put too much technology forward without thinking about the human side then in the future it will have a dangerous impact. Society 5.0 tends to lead to the security of using a technology itself and what its importance is. Society 5.0 is a time when technology becomes a part of humanity.

Nikolic, et all., (2019) in his research suggested that there are several factors that affect the performance of MSMEs, among others: individual characteristics of MSME owners, namely those related to demographic aspects, one of which is related to the ability to manage businesses. Then the internal 
characteristics of non-individuals one of them related to the age of the MSMEs. And the third is non-individual external characteristics, such as the location of the place of business and infrastructure.

The performance of MSMEs in Indonesia still has not shown good results. A family-based management system is one of the causes. Business management is still traditional and prioritizes family relationships rather than professional relationships. Alimudin, et al., (2019), Desiyanti, (2017), Mangantar, et al., (2017), Bismala, et al., (2014) Saunila (2019) said that innovation is a process and outcome. Each business can do innovation in accordance with the business that is run. The utilization of social media in marketing products is also one form of innovation, and if MSMEs can utilize social media optimally it will have an impact on sales performance.

Based on the phenomenon and gap reasearch that occurred eating in this study has the goal to find out how the actualization of digital marketing society 5.0 on MSMEs sasirangan cloth in the village of sasirangan.

\section{RESEARCH METHOD}

This type of research is quantitative descriptive. Quantitative descriptive is a quantitative research that forms descriptions with numbers or numeric, which is then analyzed and spelled out the meaning of the numbers. In addition, this study also uses the survey method, which is a method that collects information using questionnaires, polls, or surveys in the collection of data.

The location of this research was conducted in UMKM Kampung Sasirangan Kota Banjarmasin, namely Kampung Sasirangan Seberang Masjid and Kampung Sasirangan Sungai Jingah. The population in this study amounted to 37 shops from 2 places of Kampung Sasirangan. Sampling technique using purposive sampling technique is choosing a sample based on certain criteria. The criteria are as follows: 1) Have MSMEs Sasirangan; 2) Cloth Located in Sasirangan Village; 3) Actively carrying out their business activities; 4) Willing to fill out a shared questionnaire.

Based on these criteria, a sample of 31 stores was obtained, with the following details:

Table 1. Population Information

\begin{tabular}{|c|l|c|}
\hline No & Information & Amounth \\
\hline & Total Population & 37 \\
\hline 1 & Does not Have MSMEs Sasirangan Cloth & - \\
\hline 2 & Does not Have MSMEs Sasirangan Cloth & - \\
\hline 3 & Not actively carrying out their business activities & $(2)$ \\
\hline 4 & Not willing to fill out a questionnaire shared & $(4)$ \\
\hline & Total of samples & $\mathbf{3 1}$ \\
\hline
\end{tabular}

The variable in this study is the actualization of digital marketing in The Era of Society 5.0. These research variables were measured using research instruments contained in a questionnaire. The research instruments are as follows: 1) Long established company; 2) Number of employees owned; 3) Use of internet methods and reasons for their use; 4) Utilization of digital marketing for buying and selling transactions and the reasons for its use; 5) The form of digital marketing used.

This study uses data collection techniques including: 1) Observation, researchers conducted observation methods by making direct observations on MSMEs Kain Sasirangan in Kampung Sasirangan for the purposes of completeness and supporting the data that has been obtained;2) The division of questionnaires, researchers gave some questions to msme owners to answer in the form of questionnaires; 3) The division of questionnaires, researchers gave some questions to msme owners to answer in the form of questionnaires.

Data analysis techniques are activities after data from all respondents or other data sources is collected. The data analysis in this study is: 1) Editing or examination is a check to find out and assess the suitability and relevance of the data collected to be processed further. Things that are considered in this editing is the completeness of filling out questionnaires, readability of writing, suitability of answers, and relevance of answers; 2) Coding or code giving is the classification of answers given by respondents in accordance with the type; 3) Tabulation is a further step after the examination and code giving. In this stage the data is arranged in the form of tables to make it easier to analyze the data in accordance with the purpose of the research. results from tabulating this data in the form of percent; 4) After the data is collected and has gone through the process of editing, coding and tabulation, then the next stage is the process of analyzing the data by elaborating on the results of research in the form of words or sentences. This research focuses on the description of how many MSME Sasirangan actors have utilized digital marketing in the era of society 5.0.

\section{RESULTS AND DISCUSSION}

In this section, it is explained the results of research and at the same time is given the comprehensive discussion. Results can be presented in figures, graphs, tables and others that make the reader understand easily [11-15]. The discussion can be made in several sub-chapters.

Actualization of Digital Marketing Society 5.0 on MSMES of Sasirangan Cloth in Village Sasirangan in Banjarmasin City 
The results of this study were obtained from a survey conducted in the village of jingah river and mesa river (Jalan Seberang Mesjid). Of the 37 stores available, 31 were surveyed, while the remaining six refused to be surveyed for privacy reasons. The survey was conducted by way of a division of the cake which contains about the long standing of MSMEs, the number of employees owned, the utilization of internet methods, the use of digital marketing and the reason for using / not using digital marketing.

\section{Respondent Survey Results Based on Long Standing MSMEs}

Based on the results of the survey of respondents based on the length of the stand of MSMEs, it can be explained that MSMEs sasirangan cloth in the village of Jingah River and Mesa River (Opposite Mesa River) consists of 1-3 years as much as $34.38 \%$, 4-6 years as much as $18.75 \%$, 7-9 years as much as $15.63 \%$, 10-12 years as much as $6.25 \%$, and more than 12 years as much as $25 \%$. Figure 1 below contains an overview of the respondents.

Figure 1. Old-Standing MSME Data

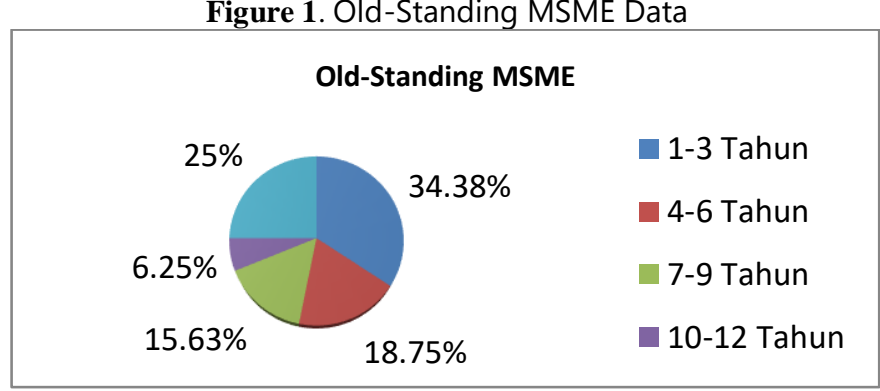

Source: processed data

Respondent Survey Results Based on Number of Employees

Based on the results of the survey based on the number of employees, MSMEs who have employees of 1 to 3 people as many as $46.88 \%, 4$ to 6 people as much as $15.63 \%$ and more than 6 people as many as $37.50 \%$. Figure 3.2 below contains an overview of the respondents.

Figure 2. Data on the Number of MSME Employees

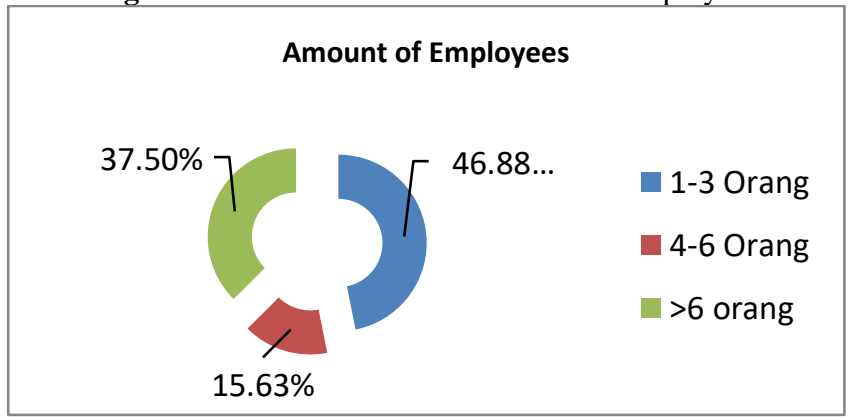

Source: processed data

\section{Respondent Survey Results Based on Utilization of Internet Methods}

Figure 3. Internet Method Utilization Data

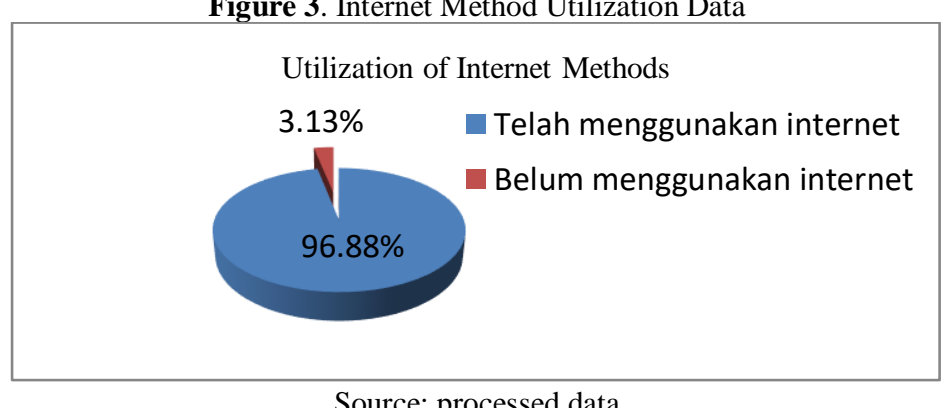

Source: processed data

Figure 3 above contains an overview of the respondent. Based on the results of the survey of the use of internet methods, it is seen that most MSMEs have utilized internet methods in daily activities, which is as much as $96.88 \%$. The Internet that MSMEs use is in terms of accessing chat services and social media $(93.75 \%)$, using for browsing $(40.63 \%)$, used to view and download images and videos $(78.13 \%)$, used to read articles as much as (12.5\%), email usage (15.63\%), access banking services as much as (37.5\%), used to get market information as much as $(56.25 \%)$, used for children's school needs $(34.4 \%)$, and used for business

International Journal of Research in Vocational Studies, Vol. 1, No. 3, December 2021: 62 - 67 
purposes that is as much as $(93.8 \%)$. Then as many as $3.13 \%$ have not used the internet in daily activities because they do not know how to use the internet.

\section{Respondent Survey Results Based on Digital Marketing Use}

From the results of the survey it is known that MSMEs have used digital marketing which is as much as $93.75 \%$ and the remaining $6.25 \%$ use the traditional way of opening their own store in the sale of their fabric products. Applications that are widely used by MSMEs in marketing their products are through social media such as Instagram, Whatsapp, and Facebook as much as (more than 45\%). Then only a few use media such as marketplaces, websites and twitter as much as (less than 15\%).

It is known some of the reasons MSMEs prefer to use marketing digitally because of the wider market reach, easy to run, the use of more flexible time, able to increase profits, do not require space, the capital needed is not too large, and fewer employees are needed. Figure 5.4 below contains an overview of the respondents.

Figure 4. Digital Marketing Usage Data

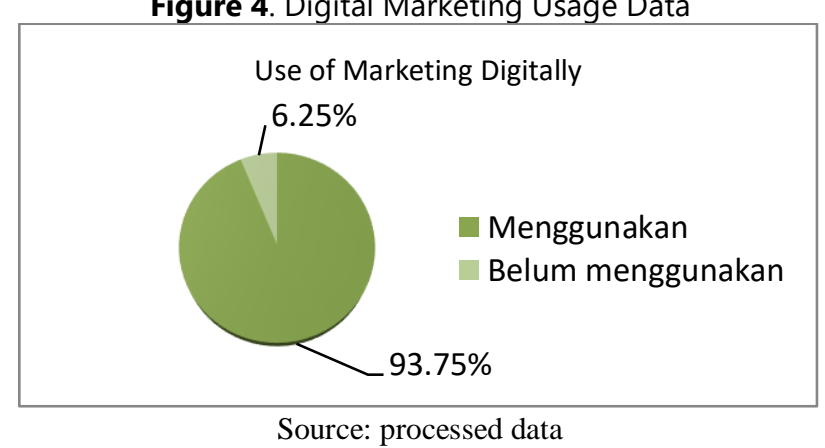

From the results of the analysis it is known that the Sasirangan MSMEs have used digital marketing in the process of buying and selling their products. It is recognized that the utilization of digital marketing can expand market reach and add new customers, facilitate business management with more flexible time, can be done at any time without having to open a store first, so that the profits obtained are also greater. In addition, by utilizing digital marketing, MSME sasirangan fabric actors do not need a place to sell their products, so the costs incurred are also less.

Not all MSME sasirangan cloth actors have been surveyed using facilities in a technology to conduct consultations in the development of Sasirangan fabric MSME business. Their lack of ability to use technology, only able to make them do marketing their products traditionally.

The results of this study are in line with research (Febriyantoro \& Arisandi, 2018) which states that the use of digital marketing helps them in informing and interacting directly with consumers. MSME actors say that the use of digital marketing expands their market share, increasing awarness for consumers because MSMEs routinely update information about products every day and increase sales because some MSMEs also collaborate with several marketplaces such as shopee and tokopedia then for MSMEs whose categories of food and beverages collaborate with go-food applications making it easier for consumers to buy their products.

Overall internet marketing is a new approach in the world of marketing that can save costs, increase customer loyalty and make orders systematically (Mokhtar, 2015). Internet marketing significantly manages information and customer relationships (Canavan, Henchion, \& O'Reilly, 2007). The role of human resources is needed for the management of MSME development, one of which is technology management, so that the mindset does not become a limitation.

\section{CONCLUSION}

The conclusion in this study is based on the results of research and discussion can be concluded that digital marketing society 5.0 on MSMEs sasirangan cloth in the village sasirangan city banjarmasin implemented in actual. Where MSMEs have utilized internet methods in daily activities, which is as much as $96.88 \%$ of the total respondents surveyed. And used for business purposes, which is as much as $93.8 \%$ based on respondents who have been surveyed. In addition, it is also supported that MSMEs have used digital marketing, which is as much as $93.75 \%$ of the total 31 respondents who have been surveyed.

\section{ACKNOWLEDGEMENTS}

The authors would like to express deep gratitude to MSMEs sasirangan cloth in the village of jingah river and mesa river (Jalan Seberang Mesjid) as well as Politeknik Negeri Banjarmasin for supporting this research. 


\section{REFERENCES}

[1] Nikolić, N., Jovanović, I., \& Nikolić, Đ. (2019). Investigation of the Factors Influencing SME Failure as a Function of Its Prevention and Fast Recovery after Failure. DE GRUYTER Entrepreneurship Research Journal, 1-21.

[2] Alimudin, A., Falani, A. Z., Mudjanarko, S. W., \& Limantara, A. D. (2019). Analisis Pengaruh Penerapan Perspektif Balanced Scorecard Terhadap Peningkatan Kinerja UMKM. Ekonika J. Ekon. Univ. kadiri, 4(1), 1.

[3] Desiyanti, R. (2017). Literasi Dan Inklusi Keuangan Serta Indeks Utilitas Umkm Di Padang. Bisman-Jurnal Bisnis \& Manajemen, 2(2), 122-134

[4] Bismala, L., \& Handayani, S. (2014). Model Manajemen UMKM Berbasis Analisis SWOT. In Prosiding Seminar Nasional PB31 ITM.

[5] Saunila, M. (2019). Innovation capability in SMEs: A systematic review of the literature. Journal of Innovation, 1-6.

[6] Febriyantoro, M. T., \& Arisandi, D. (2018). Debby Arisandi Halaman 61 dari 76 JMD. Jurnal Manajemen Dewantara, $1(2), 61-76$

[7] Mokhtar, N. F. (2015). Internet Marketing Adoption by Small Business Enterprises in Malaysia. International Journal of Business and Social Science.

[8] Canavan, O., Henchion, M., \& O'Reilly, S. (2007). The use of the internet as a marketing channel for Irish speciality food. International Journal of Retail and Distribution Management.

[9] Alimudin, A., Falani, A. Z., Mudjanarko, S. W., \& Limantara, A. D. (2019). Analisis Pengaruh Penerapan Perspektif Balanced Scorecard Terhadap Peningkatan Kinerja UMKM. Ekonika J. Ekon. Univ. kadiri, 4(1), 1.

[10] Chafey, Dave et al. Internetnet Marketing: Strategy, Implementation, and Practic. (England: pearsonEducation Limited,2000)

[11] Chaffey, Dave and Fiona Ellis-Chadwick. (2016). Digital Marketing: Strategy, Implementation and Practice. Sixth Edition. United Kingdom. Pearson.

[12] Dedi Purwana ES, Rahmi, Shandy Aditya (2016). Pemanfaatan Digital Marketing Bagi Usaha Mikro, Kecil, dan Menengah (UMKM) di Kelurahan Malaka Sari, Duren Sawit. Jurnal Pemberdayaan Masyarakat Madani (JPMM) EISSN: 2580-4332 Vol. 1 No. 1 Juli 2017

[13] Fandy Tjiptono. Strategi Pemasaran Edisi III. (Yogyakarta: Penerbit Andi, 2008), h.3

[14] Hendra Reofita, Strategi Pemasaran, (Pekanbaru: CV. Mutiara Pesisir Sumatra, 2015), h.2

[15] Mangantar, M., \& Baramuli, D. N. (2017). Usaha Mikro Makanan Tradisional Di Kelurahan Dendengan Dalam Kota Manado Tentang Manajemen Modal Kerja. Jurnal LPPM Bidang EkoSosBudKum, 3(1), 80-91.

[16] Prasanna, R. P. I. R. et al. 2019. "Sustainability of SMEs in the Competition: A Systemic Review on Technological Challenges and SME Performance." Journal of Open Innovation: Technology, Market, and Complexity 5(4):1-18.

[17] Rafi Mohammed. Internet Marketing: Building Advantage in a Networked Economy. (USA: McGraw-Hill, 2003)

[18] Sedarmayanti, Manajemen Strategi, Bandung: Refika Aditama: 2014, h.4

[19] Stockdale, R., Ahmed, A., \& Scheepers, H. (2012). Identifying Business Value from The Use of Social Media: An SME Perspective. Pacific Asia Conference on Information Systems. Association for Inforamtion System Electronic Library.

[20] Sudaryono, Manajemen Pemasaran Teori dan Implementasi, (Yogyakarta:CV Andi Offsite,2016), h.41-42

[21] Wardhana, A. (2015). Strategi Digital Marketing dan Implikasinya pada Keunggulan Bersaing UKM di Indonesia. 


\section{BIOGRAPHIES OF AUTHORS}

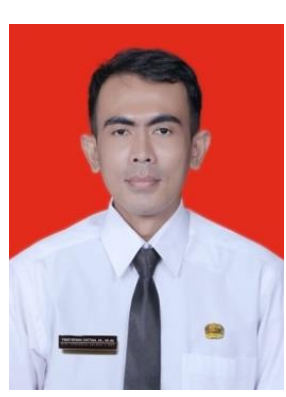

Tino Kemal Fattah, SE., M.Ak, Born in Purwosari I, May 13, 1991 is a permanent lecturer of Banjarmasin State Polytechnic Study Program DIII Accounting Department of Accounting. Completed his Bachelor's education in Accounting Study Program, Financial Accounting center, Department of Accounting STIESIA Surabaya in 2012. Master of Accounting education in Accounting study program, Public Sector Accounting concentration, Faculty of Economics and Business, National Development University "Veteran" East Java in 2017. Busy current author as a permanent lecturer of accounting who teaches courses in Public Sector Accounting, Middle Financial Accounting, Accounting Information Systems, Actual Issues of Accounting, Accounting Systems, Public Sector Accounting Practicum, Computer Accounting Practicum, Cost Accounting, Management Accounting, Financial Statement Analysis.

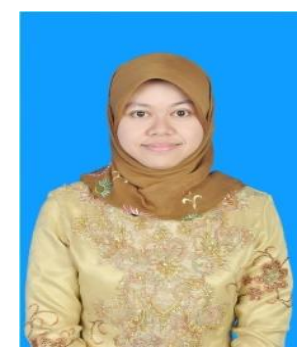

Putriana Salman, SE., Ak., M.S.A, Born in Palangkaraya, September 21, 1989 is a permanent lecturer of Banjarmasin State Polytechnic Study Program D3 Accounting Department of Accounting. Completed his Bachelor's degree in accounting department of the Faculty of Economics, Lambung Mangkurat University in 2011. Master of Accounting education at Universitas Brawijaya Malang in 2014. Busy current writer as a permanent lecturer who teaches courses Introduction to Accounting, Intermediate Financial Accounting, Professional Ethics, and Computer Accounting.Palangkaraya, September 21, 1989 is a permanent lecturer of Banjarmasin State Polytechnic Study Program D3 Accounting Department of Accounting. Completed his Bachelor's degree in accounting department of the Faculty of Economics, Lambung Mangkurat University in 2011. Master of Accounting education at Universitas Brawijaya Malang in 2014. The current busyness of writers as permanent lecturers who teach courses Introduction to Accounting, Intermediate Financial Accounting, Professional Ethics, and Computer Accounting. 